\title{
On University Expanded Training Teaching Courseware Preparation and Application Based on Authorware
}

\author{
Yu Wen ${ }^{1+}$ \\ Beijing Electronic Science and Technology Institute \\ Empirical Study on the Introduction of Expanded Training to University Physical Education (No. \\ 2014RWSK11) supported by: "The Fundamental Research Funds for the Central Universities"
}

\begin{abstract}
Based on the actual needs of expanded training course construction and features of expanded project teaching, the paper uses Authorware - a multimedia development tool to process the selected image and video materials and composes a set of comprehensive expanded training courseware for university use. During coursecare preparation, great importance has been attached to advantage, principle and technique of Authorware and course curriculum requirements of expanded training. The practical application of multimedia courseware has greatly improved the initiative of students and achieved excellent teaching results, which will be helpful to achieve the desired multimedia teaching objectives of university expanded training.
\end{abstract}

Keywords: Authorware; expanded training teaching courseware; multimedia teaching

\section{Introduction}

Multimedia teaching coureseware refers to assisted teaching software centering on computer and integrated with varied educational information including text, graphics, sound and animation by using computer programming language. As a form of modern educational technology, the application of multimedia in teaching has been welcomed and attracted wide attention. Compared with other multimedia courseware software and tools, the design and production technology of Authorware features visibility, interaction and clear logical structure, receiving massive preference from teachers. Based on practical teaching conditions, the university expanded training teaching courseware of this research uses Authorware7.0 The design and make-up process integrates modern teaching technology and expanded training teaching and combines education, science, art and technology with the purpose of improving expanded training teaching effect.

\section{Advantages of using Authorware in the preparation of university expanded training courseware}

- Authorware will, according to teaching objective of university expanded training, integrate varied teaching contents and demonstrate in form of graphics, text, audio and video.

- Authorware will, according to teaching objective of university expanded training, integrate varied training projects (including high-altitude project, medium-altitude project, low-altitude project, ground project, mental project, theoretical project and outdoor project) and demonstrate in form of varied interactive teaching.

- The hypertext function of Authorware enables the setting of hot keys in connection to university expanded training preliminary and complement knowledge, integrating training knowledge of different difficulty levels together.

\footnotetext{
+ Corresponding author. Tel: $+86-13910778470$

E-mail address:wenyudzkjdx@163.com
} 


\section{Principles of using Authorware in the preparation of university expanded training courseware}

Before making expanded training courseware by using Authorware, teaching content, the teaching level and focus shall be made clear. Modular design will be used in constructing courseware system and the principles shall be followed:

- The expanded training courseware design shall be in accordance with learning and teaching theory, the form and content shall be in conformity to rules of teaching. Basic theories including sports, education, cognitive psychology, management, sociology, organizational behavior, success, leadership and teaching design shall be read in advance to guide the preparation of courseware.

- With the purpose of serving study contents, the selection of materials shall closely center on teaching contents of university expanded training. The selection of relevant materials such as graphics, audio, animation, video shall focus on study content and highlight study objective.

- The navigation panel for university expanded training courseware should be clear and helpful for students to grasp the knowledge points of all the chapters and their inner relationship for the smooth completion of teaching objective.

- Varied interactive feedback with illustrations and graphics should be included in university expanded training courseware to effectively arouse study interests of students.

\section{Techniques of using Authorware in the preparation of university expanded training courseware}

- Before the preparation of university expanded training courseware, the style should be determined first, and then followed by detailed script witting and text, animation and audio material collection. The supported file format of Authorware merit our attention during material collection. The supported file format of Authorware includes txt and rtf. The formatting of rtf document will be preserved. The supported graphics format of Authorware includes: BMP, GIF, WMF, Photoshop3.0; the supported digital video format includes: Director, AVI, QuickTime for Windows, FLC and MPEG. Sound file with extensions such as WAV, AIFF, MP3 and SWA are also supported. The latest Authorware7.0 which is compatible with previous versions will be used in this research..

- The first step to prepare university expanded training courseware is to set the display resolution. For the default standard interface of Authorware is 640 x 480, when using Resize window function to initialize the window, the settings shall be within this range. The present popular resolution of computers is $800 \mathrm{x}$ 600 or $1024 x$ 768, which makes full-screen and centered display impossible. The correct method is as follows: click "modify" "file" "attribute" in the menu, set window resolution as 800 x 600 or 1024x 768 in the dialog box and reset the parameter in Resizewindow function.

- When making university expanded training courseware button, the built-in button tool in Authorware will be handy but the button effect is dull; the button with special effect made through professional software such as Photoshop, Ulead hotoImpact and Ulead Cool 3D will add another hue to the courseware. BMP file format will be generated for button with special effects made by Photoshop and Cool 3D. Click Window/Button and the "Button Libery" dialog box appears, then click "Add" button on the lower left and "Button Editor" appears. Two "Import" keys appear on the lower right and click the upper one, the "Import which file" appears and chose the self-made button; the lower "Import" enables WAV file input which will be accompanying sound when pressing the button.

- University expanded training courseware enables video and video clip play. During multimedia teaching software design, "digital movie" icon, "sound" icon and "video" icon are not commonly used. Instead, the relevant function will be used to achieve these functions to increase program versatility and controllability.

- When calling dynamic link library during university expanded training courseware preparation, open Data/Load Function command in start menu and Load Function dialog box, input DLL file name, function name, parameter list and return value into dialog box for custom function information to load custom function which is incompatible with Authorware; in addition, Authorware supports a transparent dynamic link library with extension UCD or U32 such as A4WMME.U32 is a multi-functional 
multimedia spread function library including media play and control function with classification of MMM animation, CD play, MIDI play and WAVE play.

- The major disadvantage of university expanded training courseware preparation by Authorware is that the courseware will take up large disk space, resulting in problems such as shortage of computer resources, unsynchronized sound and movie, broken video play and slow upload. The following techniques could be used to reduce large disk space usage: 1 . Convert wav sound file into mp3 by using mp3 tools and use plugin ActiveX or mp3player.u32 to play; 2. As for courseware background music, use midi file instead of wav file; 3 . Change courseware sound to single track; 4 . Convert animation and video files from vi, mov, flc, fli and dat format into mpg format. With highest compression ratio and supported by Authorware, mpg format could reduce disk space usage but requires XingMPEG driver for smooth play; 5. Convert simple courseware animation into gif format.

- The university expanded training courseware by Authorware could be packed into exe file and run directly on Window platform free from Authonvare platform. When packing, some driver documents should be copied to courseware directory, including required driver documents for transition effect in Xtra folder: a6qt, xmo/ a6qt32, xmo, a6vfw. smo/a6vfw32. Xmo; driver documents to load and displayBitmap file: Bmpview, x16/Bmpview. X32; driver documents to play .swf and .Gif file: awim132. Dll, vct32161. Dll, vct16151. Dll, icdllw32.dll.

- When uploading university expanded training courseware prepared by Authorware to server, Authorware web packager program could be used to pack the courseware into aam and as file. The aam file could be installed on and browse through IE or Netscape with Authorware web player plugin. Through browser, the HTML courseware could be edited and uploaded to Internet home page space to make it accessible to other people.

\section{Desired objective of university expanded training multimedia teaching}

It is a topic of practical significance to establish a teaching mode in conformity with Chinese PE course reform requirements and the development need of university students by effectively introducing expanded training to university PE curriculum resources and establishing complete curriculum design. As a kind of experience-based teaching, expanded training will be helpful for university students to cultivate their perseverance to overcome difficulties, healthy psychological quality, a positive attitude towards life and teamwork; it is also an implementation of National Physical Education Curriculum Guideline for Colleges and Universities, and an attempt at five objectives of sports participation, sports skills, physical health, mental health and social adaptation prescribed in Physical Education and Health Curriculum Standard.

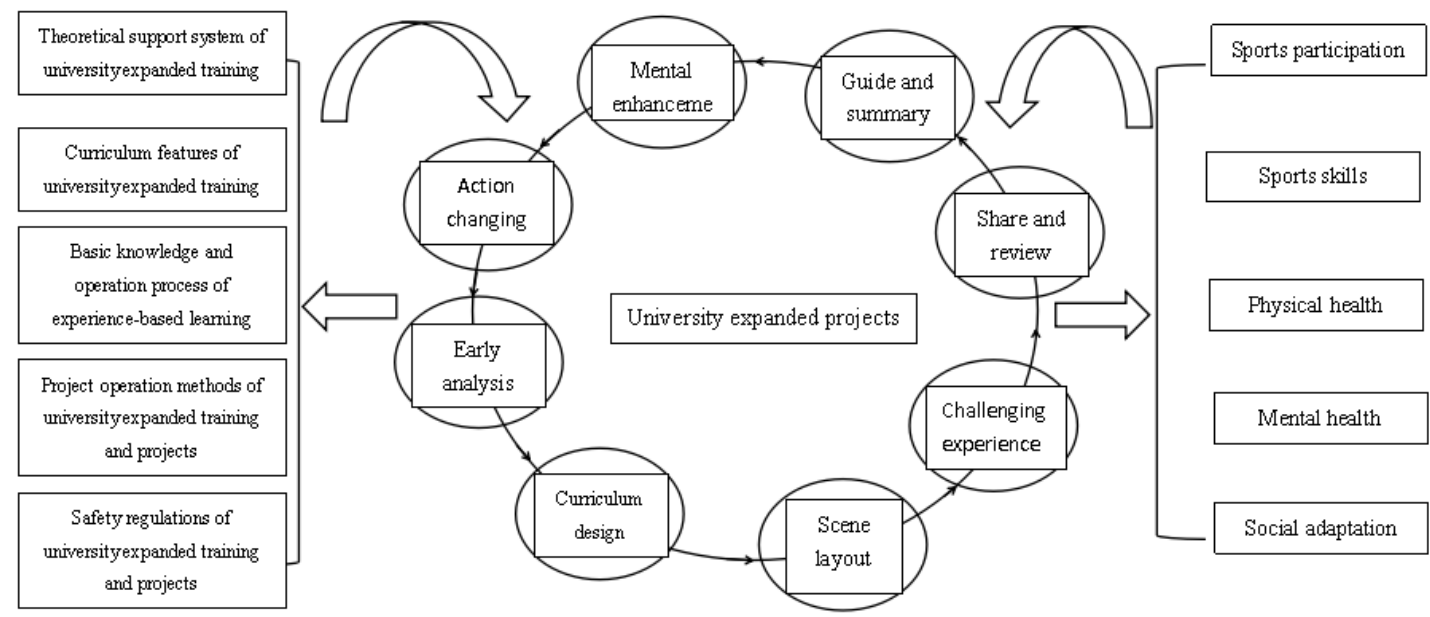

Fig. 1: Objective diagram of university expanded training multimedia teaching

Expended projects are core components in university expanded training curriculum, including highaltitude project, medium-altitude project, low-altitude project, ground project, mental project, theoretical projects and outdoor project. The university expanded training courseware in this research has drawn references from School Psychological Outward Bound by Mao Zhenming, Expanded Training by Qian Yongjian, School Expanded Training by Xie Enjie, and taken the teaching process of (early 
analysis $\rightarrow$ curriculum design $\rightarrow$ scene layout $\rightarrow$ challenging experience $\rightarrow$ share and review $\rightarrow$ guide and summary $\rightarrow$ mental enhancement $\rightarrow$ action changing) as mainline, and included teaching resources such as multimedia materials, after-class teaching reflection, student feedback, teaching expert review for the purpose of achieving desired objectives (introduce theoretical support system, curriculum features, basic knowledge and operation process of experience-based learning, project operation methods and safety regulations of university expanded training and projects). (Refer to Figure 1)

\section{Effects of university expanded training multimedia teaching}

In order to verify the effects of university expanded training multimedia teaching, the courseware has been put into use for Public PE Theory Course in Beijing Electronic Science \& Technology Institute. All the students of grade 2014 have taken part in the training, and 300 of them has been randomly sampled in expanded training class for questionnaire survey in terms of study attitude toward expanded training multimedia teaching. It can be inferred from Figure 1 that expanded training multimedia teaching is a practical application; students are highly motivated and have positive feedbacks on the teaching mode, considering that it is helpful for them to understand project operation methods and safety regulations and have a good command of action techniques. (Refer to Table 1)

Table 1: Survey on the application effect of university expanded training multimedia teaching $(n=300)$

\begin{tabular}{|l|l|l|l|}
\hline Survey contents & Agree & Neutral & Disagree \\
\hline 1. University expanded training multimedia teaching is appropriate & $99 \%$ & $1 \%$ & $0 \%$ \\
\hline 2. University expanded training multimedia teaching could stimulate your study interest & $97 \%$ & $2 \%$ & $1 \%$ \\
\hline 3. University expanded training multimedia teaching could arouse your study initiative & $98 \%$ & $2 \%$ & $0 \%$ \\
\hline $\begin{array}{l}\text { 4. University expanded training multimedia teaching is helpful for you to have a good command } \\
\text { of action techniques }\end{array}$ & $95 \%$ & $3 \%$ & $2 \%$ \\
\hline $\begin{array}{l}\text { 5. University expanded training multimedia teaching is helpful for you to understand theoretical } \\
\text { support system of the training }\end{array}$ & $92 \%$ & $6 \%$ & $2 \%$ \\
\hline $\begin{array}{l}\text { 6. University expanded training multimedia teaching is helpful for you to understand curriculum } \\
\text { features }\end{array}$ & $93 \%$ & $4 \%$ & $3 \%$ \\
\hline $\begin{array}{l}\text { 7. University expanded training multimedia teaching is helpful for you to understand basic } \\
\text { knowledge and operation process of experience-based study }\end{array}$ & $90 \%$ & $5 \%$ & $5 \%$ \\
\hline $\begin{array}{l}\text { 8. University expanded training multimedia teaching is helpful for you to understand project } \\
\text { operation method of the training }\end{array}$ & $98 \%$ & $1 \%$ & $1 \%$ \\
\hline $\begin{array}{l}\text { 9. University expanded training multimedia teaching is helpful for you to understand project } \\
\text { safety regulations of the training }\end{array}$ & $94 \%$ & $2 \%$ & $4 \%$ \\
\hline
\end{tabular}

\section{Conclusion}

The major function of university expanded training courseware is to assist teaching and demonstrate all or partial content, outline and main points of the expanded projects; simplify difficult knowledge and techniques and display teaching tutorials, graphics, animation and video; provide customized learning progress and self-study materials of different levels for project self-learning. Upon the application of university expanded training courseware to classroom teaching, we need to constantly explore, summarize and amend the courseware in teaching process and enrich its content. The advantage of multimedia courseware shall be put into full play to improve teaching practice and promote expanded training teaching.

\section{References}

[1] Zhenming Mao, Changquan Wang. School Psychological Outward Bound [M]. Beijing: Beijing Sport University Press, 2004.

[2] Yongjian Qian, Expanded Training [M]. Beijing: Beijing Enterprise Management Publishing House, 2006.

[3] Furong Li,Xiaoyue Liu. Authorware7.0 Practical Course [M]. Beijing: Tsinghua University Press, 2006.

[4] Enjie Xie,Pingmei Li,Lizhen Cheng. School Expanded Training [M]. Beijing: China Science and Technology Press, 2007.

[5] Yihua Yang, Authorware Courseware Techniques. China Modern Educational Equipment, 2012, 19:7-8 